Ekonomia - Wroclaw Economic Review 26/1 (2020)

Acta Universitatis Wratislaviensis

No 3991

https://doi.org/10.19195/2658-1310.26.1.1

Witold Kwaśnicki

ORCID: 0000-0002-8739-4991

Uniwersytet Wrocławski

witold.kwasnicki@uwr.edu.pl

\title{
Waluty krajowe czy wspólnotowe? Oto jest pytanie!
}

Artykuł nadesłany: 4.11.2019; artykuł zaakceptowany: 25.05.2020

Kody klasyfikacji JEL: E42, E52, F33, F45

Keywords: optimal currency areas, national currency, free banking

\section{Abstract}

National or Common currency? That is the question!

What currency system is conducive to economic development? Economists from various economics schools are trying to answer this question.

Different opinions of economists advocating the existence of a global currency as well as those who believe that there should be competition between currencies and the associated 'free banking' have been presented. The problems associated with the concept of optimal currency areas are also discussed. The last section discusses the controversy surrounding the question: "monetary communities or national currencies?".

Celem tego krótkiego artykułu jest przedstawienie przeglądu różnorodnych opinii dotyczących pytania o to, jaki powinien być dobry system walutowy sprzyjający rozwojowi gospodarczemu, społecznemu lub, w szerszym kontekście, rozwojowi cywilizacyjnemu. Nie jest celem tego artykułu znalezienie jednoznacznej odpowiedzi na to pytanie, ponieważ na obecnym etapie rozważań chyba nie jest to możliwe. Autorowi pozostaje jedynie nadzieja, że dzięki pokazaniu pozytywnych i negatywnych aspektów różnych rozwiązań czytelnik będzie mógł opowiedzieć się za którąś z propozycji lub też rozważania te zainspirują go do wypracowania własnego rozwiązania. Zaczniemy od przedstawienia tych najbardziej skrajnych opinii: odnoszących się do projektu jednej globalnej waluty oraz opcji jak największego zróżnicowania walut, tak by waluty te mogły z sobą w pełni konkurować. Następnie omówimy problemy związane z koncepcją optymalnych 
obszarów walutowych. W ostatniej sekcji przedyskutujmy kontrowersje wokół problemu: wspólnoty walutowe czy waluty krajowe?

\section{Waluta globalna}

Zwolennicy jednej globalnej waluty przywołują często słowa Paula Volckera przewodniczącego Rady Gubernatorów Systemu Rezerwy Federalnej (Fed) od sierpnia 1979 do sierpnia 1987, w okresie prezydentury Jimmy'ego Cartera i Ronalda Reagana. Miał on powiedzieć: „Globalna gospodarka wymaga globalnej waluty"1.

W listopadzie 2000 roku Międzynarodowy Fundusz Walutowy zorganizował forum ekonomiczne pt. One World, One Currency: Destination or Delusion?2. W trakcie dyskusji Robert Mundell przywołał postulat włoskiego ekonomisty z XVI wieku, Gaspara Scaruffiego, który chyba jako pierwszy zaproponował uniwersalną walutę o wartości opartej na wewnętrznej wartości zawartych w niej metali szlachetnych. Scaruffi doszedł do wniosku, że duża liczba i różnorodność monet $\mathrm{w}$ obiegu, jak również arbitralne praktyki prowadzące na przykład do dewaluacji, służyły jedynie ograniczaniu handlu i narażaniu kupców na nadmierne, niepotrzebne i kosztowne negocjacje. Rozwiązaniem tych problemów byłoby posługiwanie się jedną walutą ${ }^{3}$.

Idąc tym tropem, Morrison Bonpasse (2009) zaproponował stworzenie jednej globalnej waluty ${ }^{4}$. Obecnie na świecie funkcjonuje prawie dwieście różnych walut, co zdaniem Bonpasse'a bardzo komplikuje rosnącą wymianę handlową. Bonpasse uważał też, że problem ten jest dostrzegany coraz bardziej przez „zwykłych" ludzi coraz częściej podróżujących turystycznie po świecie i stających przed stałym problemem kosztownej zamiany waluty krajowej na lokalną.

Istotnym kosztem wymiany międzynarodowej jest ryzyko różnic kursów walutowych i obawa, że waluta może upaść lub podlegać presji inflacyjnej. Aby chronić się przed takim ryzykiem, konsumenci muszą kupić jakąś formę kontraktu terminowego w danej walucie, co może być bardzo kosztowne.

\footnotetext{
1 „A global economy requires a global currency”.

2 Transkrypcja dyskusji na tym forum dostępna jest pod adresem: https://www.imf.org/en/ News/Articles/2015/09/28/04/54/tr001108.

3 Gasparo Scaruffi opublikował w 1582 roku L'Alitinonfo (z greckiego 'Prawdziwe światło'). W książce tej argumentował nie tylko za uniwersalną walutą, ale także za społeczeństwem opartym na obiektywnym działaniu w świetle prawa naturalnego. Uznawał, że biznesmen dąży do swoich celów poprzez racjonalne działanie, dokonując obiektywnych szacunków szans i poziomu trudności, jakie mogą wystąpić, nie poddając się sentymentom. Idąc dalej, uznał, że taka postawa biznesmena powinna stać się powszechnym wzorcem i być obecna we wszelkich transakcjach i relacjach społecznych.

${ }^{4}$ Więcej o tej propozycji można przeczytać pod adresem: http://www.futureworldcurrency. com/ oraz https://singleglobalcurrency.org/index.html.
} 
Bonpasse twierdzi, że dzięki istnieniu jednej globalnej waluty zlikwidowanych zostanie wiele problemów współczesnego życia gospodarczego i społecznego, między innymi: bezpośrednie i pośrednie koszty transakcji z jednej waluty na drugą, problemy z bilansem płatniczym na rachunkach bieżących wszystkich krajów, ryzyko walutowe, ryzyko upadku waluty, niepewność zmian wartości spowodowana wahaniami wartości waluty w wyniku wymiany oraz kosztami zabezpieczenia w celu ochrony przed takimi wahaniami, niedopasowanie walut (misalignment of currencies). Dzięki jednej walucie zniknie konieczność utrzymywania przez kraje lub związki monetarne międzynarodowych rezerw innych walut. Ponadto, zdaniem Bonpasse, jedna globalna waluta pozwoli zmniejszyć ogólnoświatową inflację do planowanego niskiego poziomu około $2 \%$, a dzięki temu zapewnione będzie niskie oprocentowanie kredytów. Przyczyni się też do wzrostu wartości aktywów w krajach uznawanych obecnie za obarczone dużym ryzykiem. Istotne będą też korzyści płynące z emisji pieniądza (seigniorage benefit) i kontroli druku pieniądza dzięki działalności globalnego banku centralnego na rzecz pożytku publicznego. Bonpasse uważa też, że stabilna globalna waluta pozwoli na pełną realizację praw własności, tak jak to jest zapisane w przyjętej w 1948 roku przez ONZ Powszechnej deklaracji praw człowieka (Universal Declaration of Human Rights) $)^{5}$.

W opinii Bonpasse'a jednolita globalna waluta, którą będzie zarządzał globalny bank centralny w ramach globalnej unii walutowej, pozwoli zaoszczędzić 300 miliardów dolarów rocznie poprzez eliminację kosztów transakcji walutowych, wyeliminuje również potrzebę rezerw walutowych i wahania kursów walut oraz kryzysy walutowe. Ponadto oczekuje się, że wykluczenie ryzyka walutowego doprowadzi do wzrostu wartości aktywów finansowych na świecie o 36 bilionów dolarów, co z kolei doprowadzi do rocznego wzrostu PKB o 9 bilionów dolarów.

Mniej radykalną propozycję stworzenia waluty globalnej przedstawił Robert Mundell, laureat Nagrody im. Alfreda Nobla z ekonomii w 1999 roku. Mundell, będąc gościem Akademii im. Leona Koźminskiego w 2003 roku, w referacie pt. Międzynarodowy system monetarny i sprawa waluty światowej (Mundell, 2003) przypomniał, że już w 1968 roku przedłożył Podkomisji ds. Międzynarodowej Reformy Monetarnej Amerykańskiego Wspólnego Komitetu Ekonomicznego Kongresu USA plan wprowadzenia waluty światowej ${ }^{6}$. W referacie w Akademii Koźmińskiego zwrócił uwagę na to, że w skali światowej istnieją stabilne trzy

5 Artykuł 17 Deklaracji brzmi: „1. Każdy człowiek, zarówno sam jak i wespół z innymi, ma prawo do posiadania własności. 2. Nie wolno nikogo samowolnie pozbawiać jego własności”. ("1. Everyone has the right to own property alone as well as in association with others. 2. No one shall be arbitrarily deprived of his property."). Data dostępu: 21.07.2020, https://www.unesco.pl/fileadmin/ user_upload/pdf/Powszechna_Deklaracja_Praw_Czlowieka.pdf oraz https://www.un.org/en/universal-declaration-human-rights/.

${ }^{6}$ A Plan for a World Currency, Washington, D.C.: Joint Economic Committee Hearings. September 1968 . 
obszary walutowe o niskiej inflacji, mianowicie te związane z amerykańskim dolarem, euro i japońskim jenem - nazywa je ,grupą DEY”. Proponuje, by DEY było podstawą do stworzenia światowej waluty, a Międzynarodowy Fundusz Walutowy instytucją odpowiedzialną za jej dobre funkcjonowanie. Dzięki temu możliwe byłoby uniknięcie globalnego kryzysu finansowego.

Według Mundella po zmniejszeniu wahań kursowych między głównymi walutami ważona średnia tych walut - DEY - mogłaby zostać wykorzystana jako platforma do budowania globalnej waluty, którą nazwał INTOR. Gdy dolar, euro i jen ustabilizowałyby kursy walut w wąskich granicach, Rada Gubernatorów MFW wyznaczyłaby DEY jako kotwicę nowej waluty. INTOR byłaby wspierana rezerwami walutowymi, głównie walutami DEY i złotem. Każdy członek utrzymywałby swoją walutę zamienną na INTOR. Uczestnictwo byłoby dobrowolne. Państwa, które by uczestniczyły w nowym systemie, musiałyby pozwolić, aby ich politykę pieniężną regulował bilans płatniczy. INTOR byłaby wspólną walutą globalną, ale nie jedną walutą. Kraje i obszary zachowałyby swoje własne waluty, które krążyłyby razem z INTOR.

Dwa lata po wizycie w Polsce Robert Mundell opublikował artykuł pt. Sprawa waluty światowej (Mundell, 2005)7. W jego części trzeciej Mundell, przywołując Miltona Friedmana i Jamesa Meade'a jako zwolenników swobodnych kursów walutowych, przedstawia proponowanych przez nich dziewięć zalet systemu elastycznych kursów wymiany. W komentarzach neguje on każdą z tych dziewięciu zalet. Prowadzi go to do wniosku, że „eksperyment z elastycznym kursem wymiany był porażką" (Mundell, 2005). Zdaniem Mundella zmiany realnych kursów walutowych drastycznie zmniejszają zyski z handlu i dyskwalifikują argumenty zwykle stosowane przy tworzeniu stref wolnego handlu i związków celnych. Destabilizujące przepływy kapitału, zwłaszcza po 1973 roku, wstrząsnęły kursami wymiany między obszarami o wysokim i stałym stopniu stabilności cen.

Według Mudella „główna wada i główne zagrożenie dla dobrobytu w systemie światowym leży w dzikich wirach głównych kursów walutowych i ryzyku niestabilności dolara" ${ }^{8}$. Rozwiązanie tych problemów widzi ów autor w stworzeniu waluty międzynarodowej, która mogłaby być używana przez wszystkie kraje do celów handlu międzynarodowego. Osiągniecie tego stanu mogłoby się dokonać w trzech etapach. W pierwszym nastąpiłoby przejście na stabilne kursy wymiany. Po tym etapie miałoby miejsce utworzenie unii walutowej G-3 i konwergencja trzech lub czterech głównych obszarów walutowych do wspólnej jednostki rozliczeniowej, zwanej DEY, dla dolara-euro-jena lub dolara-euro-juana. W tym czasie doszłoby do ustalenia celu inflacyjnego i określenia poziomu cen w odniesieniu do DEY, zafiksowania kursów wymiany, utworzenia wspólnego komitetu polityki pieniężnej oraz do ustaleń dotyczących podziału renty emisyj-

7 Ze wstępu do tego artykułu można sądzić, że jest to zapis referatu Roberta Mundella.

8 ,[T]he major defect and the main threat to prosperity in the world system lies in the wild gyrations of major exchange rates and the risk of instability of the dollar".

Ekonomia - Wroclaw Economic Review 26/1, 2020

(C) for this edition by CNS 
nej (seniorage). W trzecim etapie Rada Gubernatorów MFW (lub instytucja specjalnie ku temu powołana) wyznaczyłaby DEY jako platformę, na której, ewentualnie w połączeniu ze złotem, zbudowana zostałaby nowa waluta światowa, którą można nazwać INTOR. Zatem na trzecim etapie dokonałby się ostateczny wybór nazwy i wartości waluty, mechanizmu i sposobu, za pomocą których zostanie ona wprowadzona, ustalenie struktury systemu walutowego i kryterium kontroli ilości waluty, sposobów jej wsparcia w postaci rezerw walutowych lub towarowych oraz lokalizacji centralnej instytucji dla tej waluty.

\section{Konkurencja między walutami i wolna bankowość}

Dwa lata po otrzymaniu Nagrody im. Alfreda Nobla z ekonomii Friedrich von Hayek opublikował dwie prace, w których zaproponował radykalną zmianę obecnego systemu monetarnego opartego na walutach krajowych i systemie banków centralnych. W pierwszym artykule o Wyborze walut (Hayek, 1976a) przedstawił radykalną propozycję zlikwidowania rządowego monopolu na emisję pieniądza i zezwolenia (narodowym) walutom na konkurowanie. Hayek pisze: ,nie mam nic przeciwko rządom emitującym pieniądze, ale wierzę, że ich roszczenia do bycia monopolistą lub ich uprawnienia do ograniczenia rodzajów pieniędzy, w których mogą być zawierane umowy na ich terytorium, czy też do określenia kursów, po których pieniądze mogą być wymieniane, jest niezmiernie szkodliwy" ". Ekonomiści zgadzają się, że konkurencja służy interesom konsumentów, a monopol zwykle szkodzi. Jednakże ci sami ekonomiści (zwłaszcza głównego nurtu) uważają, że pieniądz jest inny, że tutaj zasada konkurencji nie powinna obowiązywać. Ich zdaniem to rząd musi mieć monopol dotyczący emisji pieniądza i samodzielnie prowadzić politykę makroekonomiczną kontrolującą zmienne monetarne w celu ustabilizowania gospodarki. Hayek zakwestionował ten pogląd, stwierdzając, że jedyną prawdziwą drogą do stabilności monetarnej jest przyjęcie zasady, że tam, gdzie konkurencja jest możliwa, należy ją zmaksymalizować. Korzyści wolnego systemu walutowego są bezsporne. Jak pisze Hayek (1976a, 19): „Spraw, by było to po prostu legalne, a ludzie będą bardzo szybko odmawiać używania waluty krajowej, gdy istotnie straci ona na wartości, i będą prowadzić transakcje w walucie, której ufają"10. Hayek uważa, że taki wolny system walutowy zapewni znacznie większą stabilność systemu monetarnego i znacznie mniejsze zagrożenie inflacją. Jasno też deklaruje: „Wolę uwolnienie wszelkich transakcji pieniężnych od jakiejkolwiek unii walutowej, również dlatego, że ta ostatnia domagałaby się między-

9 „I have no objection to governments issuing money, but I believe their claim to a monopoly, or their power to limit the kinds of money in which contracts may be concluded within their territory, or to determine the rates at which monies can be exchanged, to be wholly harmful", s. 17.

10 „Make it merely legal and people will be very quick indeed to refuse to use the national currency once it depreciates noticeably, and they will make their dealings in a currency they trust". 
narodowej władzy monetarnej, która, jak sądzę, nie jest ani praktyczna, ani nawet pożądana - której trudniej byłoby zaufać niż organowi krajowemu" 11 .

$\mathrm{Na}$ końcu tego artykułu Hayek przyznaje, że proponuje w istocie likwidację obecnej polityki pieniężnej i uznaje, ,że najlepsze, co państwo może zrobić w odniesieniu do pieniędzy, to zapewnienie ram prawnych, w ramach których ludzie mogą rozwijać instytucje monetarne, które najlepiej im odpowiadają"12.

Hayek swoją propozycję wolności wyboru walut radykalizuje w następnej publikacji, postulując prywatyzację i denacjonalizację pieniądza (Hayek, 1976b). Dwa lata później opublikował on uzupełnioną wersję pracy (Hayek, 1978 (2019)). Hayek nie był przeciwnikiem pieniądza krajowego, postulował, by oprócz niego mogły być emitowane inne pieniądze (prywatne). Wyrażał przekonanie, że w wyniku zaistnienia konkurencji pomiędzy wszystkimi funkcjonującymi na rynku pieniędzmi pieniądz krajowy będzie stopniowo eliminowany. Jakub Chmielniak we wprowadzeniu do polskiego wydania Denacjonalizacji pieniadza wyraził pogląd, że obecnie rolę takich prywatnych pieniędzy mogą odegrać kryptowaluty ${ }^{13}$.

Warto zauważyć, że Hayek napisał te prace, mając prawie osiemdziesiąt lat, a więc już po opublikowaniu swoich najbardziej znanych dzieł i po okresie dogłębnej analizy wszelkich ekonomicznych argumentów za reformą monetarną i zbadaniu politycznej wykonalności różnych propozycji. W przekonujący sposób wykazuje on istotną niefunkcjonalność pieniędzy rządowych i wzywa do pełnego wolnego rynku w produkcji i dystrybucji pieniędzy oraz zarządzaniu nimi ${ }^{14}$.

Kontynuatorami myśli Hayeka są między innymi Kevin Dowd, George Selgin i Hans F. Sennholz (na przykład Dowd, 1988, 1989, 1993; Selgin, 1988a, 1988b, 1996; Sennholz, 1985). Pod wieloma względami propozycje Dowda są bardziej radykalne niż radykalizm Hayeka ${ }^{15}$; szczególny radykalizm Dowda widoczny jest w propozycji prywatnego pieniądza. Projekty wolnej bankowości przedstawione przez Dowda są logiczną i spójną wizją dokonania deregulacji finansowej, która zmusiłaby system monetarny do większej konkurencyjności i mniejszej podatności na manipulacje ze strony krajowych władz monetarnych.

11 „I prefer the freeing of all dealings in money to any sort of monetary union also because the latter would demand an international monetary authority which I believe is neither practicable nor even desirable — and hardly to be more trusted than a national authority", s. 11.

12, ,[T]he best the state can do with respect to money is to provide a framework of legal rules within which the people can develop the monetary institutions that best suit them", s. 22.

13 Z taką opinią nie zgadza się Mateusz Machaj, co wyraził w recenzji tej książki: Czy Hayek przewidziat bitcoiny? Data dostępu: 2.02.2020, https://www.obserwatorfinansowy.pl/bez-kategorii/ rotator/czy-hayek-przewidzial-bitcoiny/.

${ }^{14} \mathrm{~W}$ podobnym duchu wypowiadał się inny przedstawiciel szkoły austriackiej, nauczyciel Hayeka, Ludwig von Mises. Ze względu na ograniczone ramy tego eseju nie możemy przedstawić tutaj argumentacji Misesa.

15 Zainteresowanym wolną bankowością, jej historią, propozycjami teoretycznymi i dyskusją odnośnie do polityki monetarnej polecić można trzytomowe dzieło pod redakcją Lawrenca White'a: Free Banking, vol. 1: Nineteenth Century Thought; vol. 2: History; vol. 3: Modern Theory and Policy; Aldershot, U.K.: Edward Elgar, 1993. 
W obronie teorii i praktyki wolnej bankowości, likwidacji obecnego systemu scentralizowanej emisji pieniądza opartej na bankowości centralnej występują też George Selgin i Hans Sennholz. Rozwijają oni argumenty Hayeka i uważają, że jedynie konkurencja na rynku pieniądza zapewnia zarówno zachęty, jak i informacje niezbędne do utrzymania równowagi monetarnej. Wolna bankowość to jedyny system monetarny, który może odpowiednio dostosować się do zmian popytu rynkowego na banknoty, nie powodując niepotrzebnego wzrostu podaży pieniądza (jak to jest w przypadku pieniądza fiducjarnego).

Sennholz opublikował w 1979 roku Age of Inflation i kontynuował te rozważania w książce z 1985 roku pt. Money and Freedom. Punktem wyjścia rozważań Sennholza w Money and Freedom jest krytyka polityki pieniężnej popieranej przez tak zwane wolnorynkowe szkoły myślenia makroekonomicznego (zwłaszcza monetarystów i ekonomii podaży), po czym w ostatniej, trzeciej części proponuje swój oryginalny program demonopolizacji i powrotu do „zdrowego pieniądza”.

\section{Optymalne obszary walutowe}

Optymalny obszar walutowy odnosi się do pewnego regionu lub zbioru państw, w którym jest możliwe wprowadzenie wspólnej waluty (ewentualnie sztywnego kursu pomiędzy walutami krajowymi i zachowanie kursu płynnego w stosunku do walut krajów trzecich). Utworzenie optymalnego obszaru walutowego jest związane ze spełnieniem kilku ważnych warunków (zwłaszcza odnoszących się wewnętrznej mobilności czynników produkcji). Zdaniem zwolenników tej koncepcji funkcjonowanie optymalnego obszaru walutowego ma doprowadzić do maksymalizacji efektywności ekonomicznej na tym obszarze.

Pisząc o optymalnych obszarach walutowych, należy zacząć od pracy Roberta Mundella (1961), powszechnie uważanego za twórcę tej koncepcji ${ }^{16}$. Zdaniem Mundella zaletami wprowadzenia wspólnej waluty na danym obszarze mają być niższe koszty transakcyjne, brak ryzyka walutowego i większa przejrzystość cenowa. Natomiast potencjalną wadą wynikającą z eliminacji kursu wymiany między uczestnikami unii walutowej jest niemożliwość reagowania na tak zwane asymetryczne szoki wpływające na różne kraje (regiony) unii walutowej. Jak wskazuje Mundell, tam, gdzie nie ma mobilności czynników produkcji, szoki asymetryczne mogą zostać wchłonięte przez zmianę kursu wymiany, ale aby tak się stało, dotknięte kraje muszą mieć swoje własne waluty. W przypadku unii walutowej taka

16 Niekiedy wskazuje się, że podobną koncepcję przedstawił Abba Lerner w wydanej w 1944 roku książce The Economics of Control: Principles of Welfare Economics. Praca Mundella rozwinięta została parę lat później przez Ronalda McKinnona (1963) i Petera Kenena (1969). Warto zwrócić uwagę, że w modelach formalnych Mundell i kontynuatorzy jego idei analizują sytuację dwóch krajów. Otwartym pytaniem jest, do jakiego stopnia wnioski z tych modeli mogą być uogólniane na sytuacje tworzenia „optymalnego obszaru walutowego”, w którym funkcjonuje kilka, a nawet kilkanaście krajów.

Ekonomia - Wroclaw Economic Review 26/1, 2020

(C) for this edition by CNS 
reakcja na asymetryczne szoki jest możliwa tylko w przypadku pełnej mobilności czynników produkcji (zwłaszcza mobilności siły roboczej).

Warunkiem dobrego funkcjonowania unii walutowej jest też dywersyfikacja eksportu (co zmniejsza wpływ wstrząsów na gospodarkę wąskiej kategorii produktów eksportowych). W przypadku krajów pragnących przystąpić do unii brany pod uwagę jest stopień otwartości gospodarczej tego kraju. Im bardziej otwarta gospodarka, tym bardziej wrażliwa będzie na wstrząsy i tym mniej stabilna i płynna będzie jej waluta. Twierdzi się, że dla otwartej, zdywersyfikowanej gospodarki korzyści płynące z przystąpienia do unii walutowej pod względem zysków płynności i stabilności finansowej mogą zrównoważyć dodatkowe koszty dostosowania, które mogą wyniknąć z przystąpienia do unii.

Punktem różniącym zwolenników unii walutowej jest kwestia integracji gospodarczej. Niektórzy z nich uznają, że doprowadzenie do wysokiego poziomu integracji gospodarczej jest warunkiem wstępnym (a nawet koniecznym) do wprowadzenia unii walutowej, inni uważają, że to właśnie unia walutowa może sprzyjać integracji gospodarczej i wspierać nawet ją przy początkowo niskim jej poziomie.

Naturalną konsekwencją wprowadzenia jednej waluty w unii jest konieczność powołania regionalnego (unijnego) banku centralnego. Prowadzenie skoordynowanej, ,centralnej”, polityki monetarnej jest dla zwolenników istnienia obszarów walutowych czymś oczywistym.

Rzadziej natomiast dyskutowanym problemem wśród zwolenników unii walutowej jest kwestia skoordynowanej centralnej polityki fiskalnej. Transfery fiskalne między krajami w unii walutowej mogłyby złagodzić skutki wstrząsów asymetrycznych. Transfery dochodów z krajów mniej dotkniętych szczególnym szokiem mogą zrekompensować utratę dochodów i pomóc utrzymać zatrudnienie i zaangażowany kapitał w innych regionach. Przy ocenie zakresu transferów fiskalnych konieczne jest odróżnienie dwóch ról polityki fiskalnej, mianowicie stabilizacji transferów w różnych kierunkach w różnych latach i redystrybucji (transfery w podobnych kierunkach w czasie). Często uznaje się, że redystrybucja jest mniej istotna dla powodzenia unii walutowej niż stabilizacja, a ta ostatnia może w zasadzie być wykonywana przez rządy krajowe. Unia walutowa może wymagać większej krajowej elastyczności fiskalnej, a to może być sprzeczne z unijnymi regułami fiskalnymi.

Dosyć rzadko dyskutowanym problemem w kontekście dobrego funkcjonowania unii walutowej są kwestie kulturowe, zwłaszcza dotyczące wspólnego języka i wspólnych doświadczeń historycznych.

\section{Wspólnoty walutowe a waluty krajowe}

W świetle przedstawionej dyskusji możemy stwierdzić, że nie ma jednoznacznej i wspólnej odpowiedzi ekonomistów na pytanie, jak powinien wyglądać efek- 
tywny system monetarny. Jak w wielu innych przypadkach, i tutaj nie ma zgody wśród ekonomistów ${ }^{17}$. Pomijając nawet dwie skrajne wizje (jednej globalnej waluty i wolnej bankowości), o których mowa w pierwszych dwóch sekcjach, trudno znaleźć konsensus nawet w grupie ekonomistów głównego nurtu ${ }^{18}$.

Dobrym przykładem kontrowersji wokół koncepcji unii walutowej jest tocząca się od ponad 20 lat dyskusja o powstałej w 1999 roku europejskiej unii gospodarczej i Walutowej (oraz Europejskiego System Banków Centralnych). Dwa lata przed wprowadzeniem euro jako waluty obowiązującej w 11 krajach ${ }^{19}$ Milton Friedman w artykule (pod znamiennym tytułem: Dlaczego Europa nie może pozwolić sobie na euro) opublikowanym w londyńskim „The Times” (Friedman, 1997b) napisał: „Elastyczne kursy wymiany są potężnym mechanizmem dostosowawczym dla [łagodzenia] wstrząsów, które w różny sposób wpływają na jednostki. Warto zrezygnować z tego mechanizmu, aby uzyskać przewagę niższych kosztów transakcji i dyscypliny zewnętrznej tylko wtedy, gdy istnieją ku temu odpowiednie alternatywy"20.

Zdaniem Friedmana Stany Zjednoczone mogą być postrzegane jako pozytywny przykład wspólnej waluty ${ }^{21}$. Sprzyjają temu wspólny język, wspólne życie kulturalne, swoboda przepływu dóbr, kapitału i ludzi, w miarę elastyczne płace i ceny oraz wspólna, federalna, polityka fiskalna (z bardzo łagodnymi zmianami w poszczególnych stanach).

Friedman uważał, że w przeciwieństwie do USA wspólny rynek europejski jest przykładem obszaru niekorzystnego dla wspólnej waluty. Europa składa się

17 Rację miał George Bernard Shaw (1856-1950), który miał powiedzieć: „If all economists were laid end to end, they would not reach a conclusion". Znana jest anegdotka przypisywana Winstonowi Churchillowi, który miał powiedzieć: „Jeżeli zamkniesz dwóch ekonomistów w pokoju, dostaniesz dwie opinie, no chyba że jednym z tych ekonomistów jest lord Keynes, w takiej sytuacji dostaniesz trzy opinie”. Podobnie prezydent Harry Truman mówił o „dwurękich ekonomistach” („two-armed economists”), którzy zwykłe doradzali mu, mawiając „z jednej strony doradzałbym...”" (,on the one hand"), ale po dłuższej lub krótszej tyradzie zwykli dodawać, że „z drugiej strony...” („one the other hand”) i mówili całkiem coś przeciwnego. Dlatego Truman zwykł wołać: „Przyślijcie mi ‘jednorękiego' ekonomistę i doradcę, który nie będzie stale proponował mi przekładańca” („Give me a one armed economist and an adviser who wouldn't waffle”).

18 Dobrym przykładem wydaje się dyskusja pomiędzy dwoma laureatami Nagrody im. Alfreda Nobla z ekonomii: "Robert Mundell and Milton Friedman debate the virtues — or not — of fixed exchange rates, gold, and a world currency". Zapis tej debaty dostępny pod adresem: https:// policyoptions.irpp.org/magazines/one-world-one-money/one-world-one-money/.

19 Obecnie takich krajów, będących członkami Unii Europejskiej, jest 19 (z 28 członków UE — w 2019 roku), ponadto cztery państwa spoza UE podpisały umowy o układzie monetarnym z UE oraz dwa państwa dokonały ,jednostronnej euroizacji” swojej waluty.

20 „Flexible exchange rates are a powerful adjustment mechanism for shocks that affect the entities differently. It is worth dispensing with this mechanism to gain the advantage of lower transaction costs and external discipline only if there are adequate alternatives."

21 Warto jednak pamiętać, że historia unii walutowej w USA ma dwusetletnią historię, a jej początki, u zarania odzyskania niepodległości przez Stany Zjednoczone, były bardzo burzliwe, pełne swego rodzaju „sztuczek politycznych” (zwłaszcza w Kongresie). 
z różnych narodów, które nie mają wspólnego języka ani podobnych zwyczajów - poczucie obywatelskości nie dotyczy wspólnoty europejskiej, lecz ich własnych krajów (a często nawet regionów europejskich); pomimo europejskiej strefy wolnego handlu, ludzie, towary i kapitał przemieszczają się mniej swobodnie niż w Stanach Zjednoczonych.

W podobnym duchu wypowiada się Martin Feldstein (2010), wskazując na trzy kluczowe uwarunkowania ekonomiczne - żadne z nich nie istnieje w Europie - które pozwalają zróżnicowanym stanom USA działać w ramach jednej waluty, a mianowicie: „mobilność siły roboczej, elastyczność płac i centralna władza budżetowa"22. Zdaniem Feldsteina euro było promowane jako niezbędne dla wolnego handlu pomiędzy krajami członkowskimi pod hasłem „Jeden rynek, jeden pieniądz” („One Market, One Money”). W opinii Feldsteina, aby handel mógł się rozwijać, nie jest potrzebna jedna waluta lub stały kurs wymiany. Jako przykład na to podaje Północnoamerykański Układ Wolnego Handlu (NAFTA), przyczyniający się do zwiększenia się handlu między Kanadą, Meksykiem i Stanami Zjednoczonymi, z których wszystkie mają inne, zmienne kursy walutowe. Podobnie jest w przypadku Japonii, Korei Południowej i wielu innych dużych krajów azjatyckich, których wolumen handlu międzynarodowego rośnie, a które też mają bardzo elastyczne kursy wymiany.

Prawie dwadzieścia lat temu Beddoes (1999), Rogoff (2002) i Mundell (2003) wyrazili opinię, że obserwowana tendencja do zmniejszania się liczby walut w skali globalnej będzie skutkować dominacją, w perspektywie kilkudziesięciu lat, dwóch-trzech głównych regionów walutowych. Czy dziś powtórzyliby te prognozy?

W konkluzji swoich rozważań na temat optymalnych obszarów walutowych Robert Mundell (1968b), odpowiadając na pytanie, czy system elastycznych kursów wymiany może działać skutecznie i wydajnie we współczesnej gospodarce światowej, stwierdził, że aby było to możliwe, należy wykazać, że: (1) międzynarodowy system cen oparty na elastycznych kursach wymiany jest dynamicznie stabilny po uwzględnieniu działań spekulacyjnych; (2) zmiany kursu wymiany, niezbędne do wyeliminowania normalnych zakłóceń dynamicznej równowagi, nie są tak duże, aby spowodować gwałtowne i odwracalne przesunięcia między eksporterami i importerami; (3) ryzyko wynikające ze zmiennych kursów walutowych może zostać zneutralizowane względnie niskimi kosztami funkcjonowania rynków terminowych; (4) banki centralne powstrzymają się od spekulacji monopolistycznych; (5) dyscyplina monetarna będzie podtrzymywana przez niekorzystne konsekwencje polityczne utrzymującej się deprecjacji i jest do pewnego stopnia utrzymywana przez zagrożenia wobec poziomu rezerw walutowych; (6) można zapewnić rozsądną ochronę dłużników i wierzycieli, tak aby możliwe było utrzymania rosnącego poziomu długoterminowych przepływów kapitału;

22, ,L]abor mobility, wage flexibility, and a central fiscal authority”.

Ekonomia - Wroclaw Economic Review 26/1, 2020

(C) for this edition by CNS 
(7) płace i zyski nie są powiązane ze wskaźnikiem cen, w którym towary importowane są silnie ważone.

Wydaje się, że zadowalającą, pozytywną odpowiedź na te pytania można wysnuć z rozważań i argumentów przedstawianych przez ekonomistów będących zwolennikami wolnej bankowości. Mundell (1968b) natomiast uznaje:

argument stabilizujący dla elastycznych kursów wymiany jest zasadny tylko wtedy, gdy opiera się na regionalnych obszarach walutowych. Jeśli świat można podzielić na regiony, z których każdy ma wewnętrzną mobilność czynników produkcji i między którymi występuje czynnik ograniczający tę mobilność, to każdy z tych regionów powinien mieć oddzielną walutę, która podlega wahaniom w stosunku do wszystkich innych walut ${ }^{23}$.

Zgodnie z traktatami unijnymi Europejski Bank Centralny jest niezależny w zakresie prowadzonej przez siebie polityki pieniężnej. Niezależność ta związana jest z czterema elementami: niezależnością polityczną (niewpływaniem na decyzje EBC instytucji lub organizacji unijnych, rządów państw członkowskich i żadnych innych organów oraz niemożliwością udzielania przez EBC kredytów organom wspólnotowym lub podmiotom sektora publicznego w poszczególnych krajach), niezależnością personalną (na przykład pięcioletnia kadencyjność prezesów EBC i krajowych banków centralnych oraz ośmioletnia kadencyjność członków zarządu EBC bez możliwości wyboru na kolejną kadencję), niezależnością finansową (między innymi rozdzielność finansów EBC i finansów Unii Europejskiej) oraz niezależnością funkcjonalną (EBC ma przyznane wszelkie instrumenty i kompetencje, które są niezbędne do sprawnego prowadzenia polityki pieniężnej).

Czy doświadczenia ponad dwudziestu lat funkcjonowania EBC w pełni potwierdzają istnienie tych niezależności, a zwłaszcza niezależności politycznej i funkcjonalnej? Tutaj można mieć sporo wątpliwości, ale to temat na osobne rozważania.

\section{Bibliografia}

Beddoes, Z. (1999). From EMU to AMU. Foreign Affairs, 78, 4, July/August, pp. 8-13.

Bonpasse, M. (2009). The Single Global Currency - Common Cents for The World. Newcastle, ME USA: Single Global Currency Association.

Dowd, K. (1988). Private money: The path to monetary stability. Hobart Paper, 112. London: IEA. Dowd, K. (1989). The State and the Monetary System. Oxford: Philip Allan.

Dowd, K. (1993). Laissez-faire banking. London-New York: Routledge.

Feldstein, M. (2010). The euro's fundamental flaws. The International Economy. Data dostępu: 22.05.2019, http://www.international-economy.com/TIE_Sp10_Feldstein.pdf.

23, ,[T]he stabilization argument for flexible exchange rates is valid only if it is based on regional currency areas. If the world can be divided into regions within each of which there is factor mobility and between which there is factor immobility, then each of these regions should have a separate currency which fluctuates relative to all other currencies. This carries the argument for flexible exchange rates to its logical conclusion", s. 186. 
Friedman, M. (1960). A Program for Monetary Stability. New York: Fordham University Press, reprinted in 1983.

Friedman, M. (1997a). The euro: Monetary unity to political disunity? Project Sindicate. https:// www.project-syndicate.org/commentary/the-euro-monetary-unity-to-political-disunity.

Friedman, M. (1997b). Why Europe can't afford the euro. The Times, November 19, 1997. London.

Hallwood, C.P., MacDonald, R., (2000). International Money and Finance, 3rd ed. July. Wiley-Blackwell.

Hayek, F.A. (1976a). Choice in currency: A way to stop inflation (with commentaries by Ivor F. Pearce, Harold B. Rose Douglas Jay, sir Keith Joseph). Hobart Paper, 70. London: IEA.

Hayek, F.A. (1976b). Denationalisation of money: An analysis of the theory and practice of concurrent currencies. Hobart Paper, 70. London: IEA.

Hayek, F.A. (1978). Denationalisation of money: The argument refined, an analysis of the theory and practice of concurrent currencies. Hobart Paper (special) 70, IEA, 2nd ed.; polskie wydanie: (2019). Denacjonalizacja pieniądza. przekład i wprowadzenie J. Chmielniak. Kraków: Wydawnictwo Animi2.

McKinnon, R. (1963). Optimum currency areas. American Economic Review, 53.

Mill, J.S. (1848). Principles of Political Economy, 2.

Mongelli, F. (2002). New views on the optimum currency area theory: what is EMU telling us. ECB Working Paper, 138, April.

Mundell, R.A. (1961). The theory of optimum currency areas. American Economic Review, 51, 4, September, 657-665.

Mundell, R.A. (1968a). Capital mobility and stabilization policy under fixed and flexible exchange rates. International Economics, 250-271.

Mundell, R.A. (1968b), A theory of optimum currency areas. W R.A. Mundell. International Economics. New York: Macmillan, 177-186.

Mundell, R.A. (1993). EMU and the international monetary system. Oesterreichische Nationalbank working paper, 13 , July.

Mundell, R.A. (2003). The international monetary system and the case for a world currency. Distinguished Lectures Series, 12, Warsaw: Leon Koźmiński Academy of Entrepreneurship and Management (WSPiZ) and TIGER. 23 October. Data dostępu: 15.05.2019, https://www. kozminski.edu.pl/fileadmin/Kadra_i_Badania/Upowszechnienie_Nauki/Wyk\%C5\%82ady_z_ serii_Distinguished_lectures_oct23_2003.pdf.

Mundell, R.A. (2005). The case for a world currency. Journal of Policy Modeling, 27 (4), February, 465-475.

Moore, B.J. (2004). A global currency for a global economy. Journal of Post Keynesian Economics, 26, 4, Summer, 631-653.

Neuby, B.L., S.M. Barrett (2017). The case for a single currency. Journal of Advances in Economics and Finance, 2, 2, May. Data dostępu: 15.05.2019, https://dx.doi.org/10.22606/jaef.2017.22002.

Rogoff, K. (2002). Managing the world economy. The Economist, 3 August.

Selgin, G.A. (1988a). The Theory of Free Banking - Money Supply Under Competitive Note Issue. New Jersey: Rowman \& Littlefield with the CATO Institute.

Selgin, G.A. (1988b). Accommodating changes in the relative demand for currency: Free banking vs. central banking. Cato Journal, 7, 621-41.

Selgin G.A. (1996). Bank Deregulation and Monetary Order. London-New York: Routledge.

Sennholz F.H. (1985). Money and Freedom. Cedar Falls, Iowa: Center for Futures Education, Inc.

White, L.H. (1984a). Competitive payments systems and the unit of account. American Economic Review, 74, 699-712.

White, L.H. (1984b). Free Banking in Britain: Theory, Experience, and Debate, 1800-1845. Cambridge: Cambridge University Press.

White, L.H. (1987). Accounting for Non-Interest-Bearing Currency: A Critique of the Legal Restrictions Theory of Money. Journal of Money, Credit, and Banking, 19, 448-456.

Ekonomia - Wroclaw Economic Review 26/1, 2020

(C) for this edition by CNS 